\title{
HUBUNGAN KETERSEDIAAN RUANG ASI DENGAN KEBERHASILAN PEMBERIAN ASI EKSKLUSIF PADA IBU BEKERJA DI TABANAN
}

\author{
Hesteria Friska Armynia Subratha \\ Program Studi DIII Kebidanan, Sekolah Tinggi Ilmu Kesehatan Advaita Medika Tabanan \\ Korespodensi penulis: hesteria.friska@yahoo.com
}

\begin{abstract}
Abstrak
Latar belakang dan tujuan: Beberapa penelitian menunjukkan bahwa rendahnya pemberian ASI eksklusif di Indonesia dikarekan tidak tersedianya ruang ASI di tempat kerja. Penelitian ini bertujuan untuk mengetahui hubungan ketersediaan ruang ASI dengan keberhasilan pemberian ASI eksklusif pada ibu bekerja di Tabanan.

Metode: Penelitian survei cross sectional dilakukan pada ibu menyusui yang memiliki bayi umur 6-12 bulan sebanyak 39 orang yang dipilih secara convenience di Desa Dajan Peken Tabanan.

Hasil: Hasil penelitian menunjukkan sebagian besar ibu menyusui ditempat kerjanya tidak tersedia ruang ASI dapat memberikan ASI secara eksklusif pada bayinya sebesar 45,7\% dan ibu ditempat kerjanya tidak ada ruang ASI tidak memberikan ASI secara eksklusif sebesar 54,3\%. Ibu menyusui yang ditempat kerjanya tersedia ruang ASI sebesar $75 \%$ dan $25 \%$ ibu bekerja yang memberikan ASI eksklusif. Hasil uji statistik menggunakan uji chi square didapatkan hasil yaiu 0,267 dan $p$ - 0,175 sehingga hipotesis ditolak.
\end{abstract}

Simpulan: Tidak ada hubungan ketersediaan ruang ASI dengan keberhasilan pemberian ASI eksklusif pada ibu bekerja.

Kata kunci : ASI Eksklusif, Ketersediaan Ruang ASI, Ibu Bekerja

\section{Pendahuluan}

Air Susu Ibu (ASI) eksklusif yaitu cairan yang diberikan ibu kepada bayinya tanpa makanan pendamping apapun selama 6 bulan. ASI memiliki keunggulan sebagai nutrisi dibandingkan sumber nutrisi lainnya. Komposisi dan volume ASI berbeda-beda untuk setiap ibu bergantung pada kebutuhan bayi. Bayi yang mendapatkan ASI eksklusif mempunyai antibodi yang lebih tinggi dibandingkan dengan yang mendapatkan susu formula (Rizki, 2013).

Bayi disusui segera setelah lahir dan tidak diberi makanan apapun selain ASI selama 6 bulan pertama kehidupan, tidak diberikan air, ataupun makanan lain, hanya ASI saja. Dari 6 bulan hingga 2 tahun, ASI harus tetap diberikan bersama dengan makanan pendamping ASI yang aman dan bergizi. Namun di Indonesia, meskipun sejumlah besar perempuan 96\% menyusui anak mereka dalam kehidupan mereka, hanya $42 \%$ dari bayi yang berusia di bawah 6 bulan yang mendapatkan ASI eksklusif. Pada saat bayi yang akan berusia 2 tahun, hanya 55\% yang masih diberi ASI (UNICEF, 2016).

Cakupan pemberian ASI eksklusif pada seluruh bayi dibawah 6 bulan meningkat dari $58,9 \%$ pada tahun 2004 menjadi $61,3 \%$ pada tahun 2009. Cakupan bayi yang mendapat ASI eksklusif terus menerus dari usia 0-6 bulan juga meningkat dari 19,5\% tahun 2005 menjadi 34.3\% pada tahun 2009 (Survei Sosial Ekonomi Nasional, 2009).

Menurut hasil Survei Demografi Kesehatan Indonesia (2012), terdapat 28\% bayi di Indonesia yang diberikan ASI eksklusif pada tahun 2002. Angka ini meningkat menjadi 32\% pada tahun 2007. Riset Kesehatan Dasar (Riskesdas) 2013 
menyatakan bahwa pemberian ASI eksklusf pada bayi 0-1 bulan mencapai angka 52,7\% dan seiring bertambahnya usia bayi yang mencapai usia 6 bulan menjadi menurun yaitu $30,2 \%$.

Berdasarkan survei Badan Pusat Statistik (BPS) tahun 2013, jumlah angkatan kerja wanita terus meningkat setiap tahunnya. Saat ini dari 114 juta jiwa (94\%), 38\% diantaranya berada pada usia reproduktif (BPS, 2013). Faktor-faktor yang mempengaruhi kegagalan ASI yang pertama yaitu kurangnya pengetahuan ibu tentang ASI eksklusif (32\%), dimana ibu menghentikan pemberian ASI karena produksi ASI kurang. Penyebab kedua adalah ibu bekerja (28\%), sehingga ibu menghentikan pemberian ASI eksklusif karena harus kembali bekerja.Penyebab ketiga adalah gencarnya promosi susu formula (16\%), sehingga ibu menghentikan pemberian ASI akibat pengaruh iklan susu formula. Faktor lain yang menyebabkan kegagalan ASI yaitu faktor sosial budaya (24\%), yang meliputi nilai-nilai dan kebiasaan masyarakat, sehingga menghambat keberhasilan ibu dalam pemberian ASI eksklusif, faktor dukungan dari petugas kesehatan (24\%), dimana kegagalan pemberian ASI eksklusif disebabkan kurangnya dukungan dari petugas kesehatan, dan faktor dari keluarga (24\%), dimana banyak ibu yang gagal memberikan ASI Eksklusif karena orang tua, nenek atau ibu mertua mendesak ibu untuk memberikan susu tambahan formula (Bangnes, 2011).

Cakupan pemberian ASI eksklusif pada bayi usia 0-6 bulan adalah 54,3\% (Pusat Data dan Informasi, 2013). Salah satu faktor yang mempengaruhi rendahnya pemberian ASI eksklusif di Indonesia yaitu tidak tersedianya ruang ASI dibeberapa tempat kerja (Kemenkes RI, 2013). Banyak tantangan ibu bekerja dalam menyusui yang tentunya berkemungkinan akan menyebabkan kegagalan dalam memberikan ASI eksklusif, diataranya yaitu mobilitas kerja yang tinggi, dinas keluar kota atau keluar negeri, jarak kantor dengan rumah yang jauh, dan tidak tersedia ruang menyusui di kantor (Wageindicator Foundation, 2014).

Penelitian terdahulu yang dilakukan oleh Budiyanto (2015) tentang Hubungan Ketersediaan Fasilitas Penunjang Terhadap Keberhasilan ASI Eksklusif pada Ibu Bekerja sebagai tenaga kesehatan di Rumah SAKIT PKU Muhamadiyah Gombong, dimana 96,9\% ibu bekerja sebagai tenaga kesehatan di Rumah Sakit PKU Muhammadiyah Gombong tidak memberikan ASI Eksklusif dan hanya $3,1 \%$ yang memberikan ASI Eksklusif. Tingkat pemberian ASI eksklusif masih sangat rendah jika dibandingkan dengan indikator Indonesia Sehat 2010.

Cakupan ASI eksklusif di Kabupaten Tabanan tahun 2016 yaitu $68.50 \%$. Studi pendahuluan yang dilakukan di Desa Dajan Peken Tabanan dengan 5 responden didapatkan (80\%) responden mengatakan tidak tersedia ruang ASI ditempat kerja dan (20\%) responden mengatakan tersedia ruang ASI. Berdasarkan hal tersebut peneliti tertarik untuk melakukan penelitian tentang hubungan ketersediaan ruang ASI terhadap keberhasilan pemberian ASI eksklusif pada ibu bekerja.

Penelitian ini bertujuan untuk mengetahui hubungan ketersediaan ruang ASI dengan keberhasilan pemberian ASI eksklusif pada ibu bekerja.

\section{Metode Penelitian}

Peneliti menggunakan penelitian kuantitatif dengan pendekatan cross sectional dimana peneliti mempelajari kejadian secara serentak pada individu dan populasi tunggal pada satu saat atau periode tertentu. Populasi dalam penelitian ini ibu menyusui yang memiliki bayi umur 6-12 bulan di Desa Dajan Peken berjumlah 64 orang. Teknik sampel yang digunakan dalam penelitian ini adalalah convenience sampling. Setelah dimasukkan rumus didapatkan jumlah sampel 39 orang.

Dalam melakukan pengumpulan data, penelitian ini menggunakan alat pengumpulan data berupa kuesioner ketersediaan ruang ASI yang terdiri dari 9 pertanyaan. Untuk pertanyan jawaban ya skor 
1 dan jawaban tidak skor 0 , keberhasilan pemberian ASI eksklusif yang terdiri dari 4 pertanyaan, pertanyaan no 1 dan 4 jika iya skor 1 dan jika tidak skor 0 . Pertanyaan no 2 dan 3 hanya mendeskripsikan hasil jawaban responden. Kuesioner ini telah dilakukan uji validitas dan reliablitas pada 20 ibu menyusui yang memiliki bayi umur 6-12 bulan di Desa Delod Peken. Setelah didapatkan hasil bahwa kuesioner ini valid dan reliabel maka kuesioner ini dapat digunakan dalam penelitian.

Teknik analisis dalam penelitian ini adalah analisis univariat dan bivariat. Analisis univariat digunakan untuk mengetahui gambaran tentang distribusi karakteristik responden seperti umur, pendidikan, paritas, penghasilan, dan pekerjaan. Sedangkan analisis bivariat yang digunakan adalah uji chi square untuk mengetahui hubungan ketersediaan ruang ASI terhadap keberhasilan pemberian ASI eksklusif pada ibu bekerja.

\section{Hasil dan Pembahasan}

Berdasarkan tabel 1 Ibu menyusui yang berumur 20-35 tahun sebanyak $(92,3 \%)$, yang berumur $>35$ tahun sebanyak 2 orang $(5,1 \%)$ dan ibu menyusui yang berumur $<20$ tahun sebanyak $(2,6 \%$.) . Pendidikan ibu menyusui yang terdiri dari tingkat SMA sebanyak (51,3\%), S1 sebanyak
(35,9\%), D3 sebanyak (10,3\%), dan SMP sebanyak $(2,6 \%)$. Paritas ibu $\geq 2$ anak sebanyak $(56,4 \%)$ dan ibu $\leq 1$ anak sebanyak 43,6\%). Penghasilan ibu menyusui yang bekerja yaitu $\leq \mathrm{Rp} 2.000 .000$ sebanyak $66,7 \%, \quad \geq \operatorname{Rp} 2.000 .000$ sebanyak 25,6\%) dan tidak menentu sebanyak $7,7 \%$. Pekerjaan ibu menyusui swasta sebanyak $(79,5 \%$.), pegawai kontrak sebanyak 4 orang $(10,3 \%)$, tenaga kesehatan sebanyak $(5,1 \%)$ dan PNS sebanyak $(5,1 \%)$. Berdasarkan tabel 2 dapat diketahui bahwa dari 39 responden, sebanyak $89,7 \%$ di tempat kerjanya tidak tersedia ruang ASI dan sebanyak 10,3\% di tempat kerjanya tersedia ruang ASI. Berdasarkan tabel 3 dapat diketahui bahwa dari 39 responden, sebanyak 51,3\% tidak memberikan ASI eksklusif sedangkan sebanyak $48,7 \%$ yang memberikan ASI eksklusif. Berdasarkan tabel 4 bahwa sebanyak $54,3 \%$ responden tidak tersedia ruang ASI dan tidak berhasil dalam memberikan ASI eksklusif, sebanyak 45,7\% responden tidak ada ruang ASI dan berhasil memberikan ASI secara eksklusif. Di tempat responden bekerja yang ada ruang ASI tetapi tidak berhasil memberikan ASI secara ekskusif sebanyak 25\% dan responden yang ditempat kerjanya tersedia ruang ASI dan berhasil memberikan ASI secara eksklusif sebanyak $75 \%$.

Tabel 1 Distribusi Frekuensi Responden

\begin{tabular}{|c|c|c|}
\hline Keterangan & Frekuensi & Persentase (\%) \\
\hline \multicolumn{3}{|l|}{ 1. Umur } \\
\hline a) $<20$ tahun & 1 & $2,6 \%$ \\
\hline b) 20-35 tahun & 36 & $92,3 \%$ \\
\hline c) $>35$ tahun & 2 & $5,1 \%$ \\
\hline Jumlah & 39 & $100 \%$ \\
\hline \multicolumn{3}{|l|}{ 2. Pendidikan } \\
\hline a) SMP & 1 & $2,6 \%$ \\
\hline b) SMA & 20 & $51,3 \%$ \\
\hline c) D3 & 4 & $10,3 \%$ \\
\hline d) S1 & 14 & 35,9 \\
\hline Jumlah & 39 & $100 \%$ \\
\hline \multicolumn{3}{|l|}{ 3. Paritas } \\
\hline a) $\leq 1$ & 17 & $43,6 \%$ \\
\hline b) $\geq 2$ & 22 & $56,4 \%$ \\
\hline Jumlah & 39 & $100 \%$ \\
\hline
\end{tabular}




\begin{tabular}{ccc}
\hline 4. Penghasilan & & \\
a) Tidak Menentu & 3 & $7,7 \%$ \\
b) $\leq$ Rp 2.000 .000 & 26 & $66,7 \%$ \\
c) $\quad$ Rp 2.000 .000 & 10 & $25,6 \%$ \\
\hline Jumlah & $\mathbf{3 9}$ & $\mathbf{1 0 0 \%}$ \\
\hline 5. Pekerjaan & 31 & $79,5 \%$ \\
a) Swasta & 4 & $10,3 \%$ \\
b) Pegawai Kontrak & 2 & $5,1 \%$ \\
c) Tenaga Kesehatan & 2 & $5,1 \%$ \\
d) PNS & $\mathbf{3 9}$ & $\mathbf{1 0 0 \%}$ \\
\hline Jumlah & & \\
\hline
\end{tabular}

Tabel 2 Distribusi Frekuensi Berdasarkan Ketersediaan Ruang ASI

\begin{tabular}{lcc}
\hline Ketersediaan Ruang ASI & $\begin{array}{c}\text { Frekuensi } \\
(\mathbf{f ~})\end{array}$ & $\begin{array}{c}\text { Persentase } \\
(\mathbf{\%})\end{array}$ \\
\hline Tersedia & 4 & $10,3 \%$ \\
\hline Tidak Tersedia & 35 & $89,7 \%$ \\
\hline Jumlah & 39 & $100,0 \%$ \\
\hline
\end{tabular}

Tabel 3 Distribusi Frekuensi Berdasarakan Keberhasilan Pemberian ASI Eksklusif

\begin{tabular}{lcc}
\hline Keberhasilan ASI Eksklusif & $\begin{array}{c}\text { Frekuensi } \\
\text { ( f ) }\end{array}$ & $\begin{array}{c}\text { Persentase } \\
(\boldsymbol{\%})\end{array}$ \\
\hline Berhasil & 19 & $48,7 \%$ \\
\hline Tidak berhasil & 20 & $51,3 \%$ \\
\hline Total & 39 & $100 \%$ \\
\hline
\end{tabular}

Tabel 4 Hubungan Ketersediaan Ruang ASI terhadap Keberhasilan ASI Eksklusif pada Ibu Bekerja

\begin{tabular}{|c|c|c|c|c|c|c|c|c|}
\hline \multirow{3}{*}{$\begin{array}{l}\text { Ketersediaan } \\
\text { Ruang ASI }\end{array}$} & \multicolumn{6}{|c|}{ Keberhasilan Pemberian ASI Eksklusif } & \multirow[t]{2}{*}{ chi square } & \multirow[t]{2}{*}{$p-$} \\
\hline & \multicolumn{2}{|c|}{ Tidak Berhasil } & \multicolumn{2}{|c|}{ Berhasil } & \multicolumn{2}{|c|}{ Total } & & \\
\hline & $\mathrm{F}$ & $\%$ & $\mathrm{~F}$ & $\%$ & f & $\%$ & 0,267 & 0,175 \\
\hline Tidak Ada & 19 & $54,3 \%$ & 16 & $45,7 \%$ & 35 & $100 \%$ & & \\
\hline Ada & 1 & $25 \%$ & 3 & $75 \%$ & 4 & $100 \%$ & & \\
\hline Total & 20 & $\mathbf{5 1 , 3}$ & 19 & 48,7 & 39 & 100,0 & & \\
\hline
\end{tabular}

Ketersediaan Ruang ASI

Berdasarkan hasi penelitian yang dilakukan bahwa sebanyak $10,3 \%$ responden yang ditempat kerjanya disediakan ruang ASI. Menurut Hanif (2017) ketersediaan ruang ASI merupakan salah satu bentuk kepedulian bagi para pekerja perempuan yang telah menjadi ibu. Terlebih ASI eksklusif merupakan hak anak yang harus diberikan ibu, meski dalam kondisi bekerja. Jadi hasil penelitian ini tidak sejalan dengan Hanif (2017) karena kebanyakan responden $89,3 \%$ yang tidak disediakan ruang ASI sedangkan ketersediaan ruang ASI merupakan salah satu bentuk kepedulian bagi para ibu bekerja perempuan yang telah menyatakan bahwa bukan hanya gaji yang memadai dan lingkungan yang nyaman, ruang ASI perlu disediakan di tempat-tempat kerja. Sebab kehadiran ruang laktasi akan membuat karyawati terutama yang sedang memberi ASI, akan lebih produktif. Dengan menyediakan ruang menyusui tentu akan membantu ibu tersebut secara emosional dan juga fisik sebab dapat mengurangi kecemasan terhadap anak dan membuat mereka lebih produktif. Menurut Kartini (2018) hanya 64,8\% gedung perkantoran di Indonesia yang menyediakan ruang laktasi guna mendukung program ASI eksklusif. Angka tersebut merupakan kumpulan data di 19 Provinsi dan 78 Kabupaten atau Kota, 
yang sudah melaksanakan program Gerakan Perempuan Pekerja Sehat dan Produktif (GP2SP) maupun yang tidak. Menurut Sandra (2017) ketersediaan ruang ASI sangat penting karena setiap ibu menyusui pada jam tertentu harus dikeluarkan ASInya. Peralatan yang ada ketika ibu sedang bekerja, harus didukung dengan adanya ruangan khusus. Menurut Wiandani (2017) bahwa ketika ada perusahaan yang bersedia menyediakan ruang laktasi tetapi sulit diakses oleh buruh yang ingin menggunakannya. Kesulitan tersebut terjadi disebabkan karena ruang laktasi yang jauh dari ruang produksi atau ruang kerja, tidak diberikan ijin dari pimpinannya, dan ketakutan terjadinya penumpukan pekerjaan karena tidak ada yang menggantikan ketika ditinggalkan. Terkesan perusahaan telah menjalankan peraturan yang ditetapkan, akan tetapi pelaksanaannya tidak disesuaikan dengan kebutuhan dan situasi di lingkungan tempat kerja.

Keberhasilan Pemberian ASI Eksklusif pada Ibu Bekerja

1. Keberhasilan Pemberian ASI Eksklusif pada Ibu Bekerja yang Tersedia Ruang ASI

Berdasarkan hasil penelitian bahwa ibu bekerja di kantor yang tersedia ruang ASI mayoritas memberikan ASI eksklusif sebesar $75 \%$. Tersedianya ruang ASI dapat memberikan kenyamanan bagi ibu menyusui yang akan memerah ASInya. Selain itu fasilitas yang lengkap dan mendukung sangat membantu ibu dalam memerah ASI sehingga ibu dapat memberikan ASI eksklusif pada bayinya. Data yang diperoleh dari 9 pernyataan dengan menggunakan kuesioner terkait ruang ASI didapatkan hasil bahwa fasilitas ruang menyusui sudah memenuhi persyaratan kesehatan ruang ASI dengan 9 jawaban iya.

Menurut Permenkes no 15 tahun 2013 terkait penyediaan fasilitas ruang ASI di tempat kerja, syarat kesehatan ruang ASI yaitu tersedia ruang untuk ibu menyusui, berisi pintu yang dapat dikunci, memiliki ventilasi dan sirkulasi udara yang cukup, terhindar dari kebisingan, tidak terpapar oleh polusi asap rokok, dan lembab, tersedia kursi, tisu, lap, kulkas untuk menyimpan ASI perah dan tersedia wastafel untuk mencuci tangan dan peralatan.

Walaupun terdapat ruang ASI dengan fasilitas mendukung untuk keberhasilan pemberian ASI eksklusif namun, terdapat sebanyak 25\% ibu yang tersedia ruang ASI tetapi tidak memberikan ASI eksklusif. Penyebab ibu tidak memberikan ASI eksklusif karena pemikiran ibu bahwa ASI yang keluar sedikit pada malam hari bayinya menangis sehingga ibu memutuskan untuk memberikan susu formula dan ibu sudah memberikan makanan pendamping ASI seperti bubur, biskuit, dan pisang pada umur bayi 4 bulan.

Penelitian yang dilakukan sejalan dengan penelitian yang dilakukan oleh Arum (2015) bahwa ibu yang bekerja di PT yang tersedia ruang menyusui mayoritas memberikan ASI eksklusif sebanyak $37 \mathrm{ibu}$ $(69,82 \%)$. Tersedianya pojok ASI pada PT memberikan kenyamanan kepada ibu menyusui ketika akan memerah ASI di tempat kerja. Selain itu fasilitas yang lengkap dan mendukung di ruang menyusui sangat membantu ibu dalam memerah ASI sehingga ibu dapat memberikan ASI eksklusif pada bayinya. Data yang diperoleh dari 11 pernyataan dengan menggunakan ceklist terkait ruang menyusui didapatkan hasil bahwa fasilitas ruang menyusui sudah memenuhi persyaratan kesehatan ruang ASI dengan 11 jawaban iya.

2. Keberhasilan Pemberian ASI Eksklusif pada Ibu Bekerja yang Tidak Tersedia Ruang ASI

Berdasarkan data yang didapatkan bahwa mayoritas ibu bekerja dikantor yang tersedia ruang ASI tidak memberikan ASI eksklusif sebesar 54,3\%. Hal ini disebabkan ibu yang bekerja atau berada diluar rumah akan memberikan bayinya susu formula ataupun makanan pendamping ASI sebelum bayi berumur 6 bulan.

Penelitian ini sejalan dengan penelitian yang dilakukan oleh Arum (2015) diketahui 
bahwa hasil penelitian menunjukkan bahwa ibu yang bekerja di PT (Perseroan Terbatas) yang tidak tersedia ruang menyusui mayoritas tidak memberikan ASI eksklusif sebanyak $64,15 \%$. Tidak tersedianya ruang menyusui di tempat kerja membuat ibu mengalami kesulitan dalam menemukan tempat yang nyaman untuk memerah ASI, maka perlu menjadi perhatian bagi pihak PT untuk memberikan ruang pojok ASI di tempat kerja agar ibu tetap dapat memberikan ASI eksklusif pada bayinya.

Penelitian yang dilakukan oleh Rizkiandini (2014) bahwa ibu bekerja yang mempunyai balita tidak diberi ASI eksklusif sebanyak $46,4 \%$. Ibu tidak memberikan ASI eksklusif karena ibu sebagian besar bekerja bila sudah bekerja, kadang ibu tidak mau direpotkan dengan kegiatan dalam memompa ASI. Bekerja juga merupakan sumber ketegangan dan stress yang besar bagi para ibu bekerja. Kondisi fisik dan mental yang lelah setelah bekerja sepanjang hari telah menghambat kelancaran produksi ASI. Selain itu juga ada faktor budaya setempat yang tidak biasa memberikan ASI eksklusif terhadap bayinya, atau memberikan ASI dengan ditambah minuman lainya sebelum usia 6 bulan.

Hubungan Ketersediaan Ruang ASI Terhadap Keberhasilan Pemberian ASI Eksklusif Pada Ibu Bekerja

Berdasarkan hasil penelitian yang telah dilakukan bahwa sebanyak 45,7\% responden yang tidak tersedia ruang ASI dan dapat memberikan ASI secara eksklusif. Menurut Arum (2015) di Sleman Yogyakarta menunjukkan bahwa, ibu yang bekerja di PT yang tersedia ruang menyusui mayoritas memberikan ASI eksklusif sebanyak $37 \mathrm{ibu}$ $(34,91 \%)$. Jadi penelitian ini tidak sejalan dengan penelitian Arum (2015) karena pada penelitian ini kebanyakan responden berhasil memberikan ASI secara eksklusif karena dukungan keluarga, dan teman sebaya sedangkan di Sleman ibu yang bekerja yang tersedia ruang menyusui kebanyakan memberikan ASI secara eksklusif.
Berdasarkan hasil penelitian yang dilakukan di Desa Dajan Peken dapat disimpulkan bahwa tidak ada hubungan ketersediaan ruang ASI terhadap keberhasilan pemberian ASI eksklusif pada ibu bekerja. Hal ini dapat dillihat dari tabel $2 \times 2$ ini layak untuk diuji dengan chi square karena tidak ada nilai yang kurang dari lima. Nilai yang yang dipakai adalah pada nilai pearson chi square. Nilai significancynya adalah 0,079 berarti tidak ada hubungan ketersediaan ruang ASI terhadap keberhasilan pemberian ASI eksklusif pada ibu bekerja. Penelitian ini hampir sama dengan Budiyanto (2015) bahwa 43,8\% responden mempunyai ruang asi dan $56,3 \%$ tidak menyediakan ruang ASI. Dari hasil uji chi square diperoleh hasil $\mathrm{p}$ value ruang ASI $=1,00$ dan wastafel $=1,00$. Yang dapat disimpulkan bahwa tidak hubungan ketersediaan fasilitas penunjang terhadap keberhasilan ASI eksklusif pada ibu bekerja sebagai tenaga kesehatan di RS PKU Muhamadiyah Gobong. Jadi penelitian ini sejalan dengan penelitian yang dilakukan Budiyanto (2015) yang menyatakan bahwa tidak ada hubungan tenang hubungan ketersediaan fasilitas penunjang terhadap keberhasilan pemberian ASI eksklusif pada ibu bekerja sebagai tenaga kesehatan. Penelitian yang dilakukan oleh Abdullah (2013) yang menunjukan tidak terdapat hubungan bermakna antara ketersediaan fasilitas di kantor dengan pemberian ASI eksklusif. Berdasarkan penelitian ini,pekerja. Meskipun kantor menyediakan pojok ASI, ibu bekerja lebih memilih memerah ASI saat di rumah. Ketika di kantor, ibu menyusui tidak selalu memerah di pojok ASI, tetapi dapat melakukannya di klinik kantor, di ruang kerja, dan di mushola. Jadi penelitian ini juga sejalan dengan penelitian yang dilakukan oleh Abdullah (2013) bahwa tidak ada hubungan ketersediaan ruang ASI terhadap keberhasilan pemberian ASI esklusif pada ibu bekerja. 


\section{Simpulan}

Ibu menyusui yang ditempat kerjanya menyediakan ruang ASI di Desa Dajan Peken Tabanan sebesar 75\%. 2. Ibu menyusui yang bekerja memberikan ASI eksklusif di Desa Dajan Peken Tabanan sebesar 45,7\%. 3. Tidak ada hubungan yang signifikan antara ketersediaan ruang ASI terhadap keberhasilan pemberian ASI eksklusif pada ibu bekerja di Desa Dajan Peken Tabanan.

\section{Referensi}

Abdullah.2013.Determinan Perilaku Pemberian Air Susu IbuEksklusif pada Ibu Pekerja.Diakses pada tanggal 19 juli 2018 dari Http://jurnalkesmas.ui.ac.id/kesmas/artic le/view/27/28

Arum.2015.Ketersediaan Ruang Menyusui Terhadap ASI Eksklusif pada Ibu Bekerja.Diaskes pada tanggal 27 juni 2018 dari http://digilib.unisayogya.ac.id/338/1/NA SKAH\%20PUBLIKASI.pdf

Bangnes.2011.Fakor-faktor yang Memperngaruhi Kegagalan Ibu dalam Pemberian ASI Ekslusif.Diakses pada tanggal 25 april 2018 dari http://www.bangnes.com/2011/09/faktor -faktor yang mempengaruhi.html.

BPS.2013.Dukung Ibu Bekerja Beri ASI Eksklusif.Diakses pada tanggal 26 mei 2018 dari http://www.depkes.go.id/article/view/15 091400003/dukung-ibu-bekerja-beri-asi eksklusif.html

Budiyanto.2015.Hubungan Ketersediaan Fasilitas Penunjang Terhadap Keberhasilan Pemberian ASI Eksklusif pada Ibu yang Bekerja sebagai Tenaga Kesehatan. Diakses pada tanggal 25 mei 2018 dari http://download.portalgaruda.org/article. php? article $=323714 \& \mathrm{val}=4792 \&$ title $=\mathrm{H}$ UBUNGAN\%20KETERSEDIAAN\%20 FASILITAS\%20PENUNJANG\%20TE RHADAP\%20KEBERHASILAN\%20P EMBERIAN\%20ASI\%20EKSKLUSIF \%20PADA\%20IBU\%20YANG\%20BE
KERJA\%20SEBAGAI\%20TENAGA\% 20KESEHATAN

Depkes RI.2011. Ibu Bekerja Bukan Alasan Menghentikan Pemberian ASI Eksklusif. Diakses pada tanggal 25 Mei 2018 dari http://www.depkes.go.id/pdf.php?id=16 $\underline{62}$

Hanif.2017.Menangker Ingatkan Sediakan Ruang ASI.Diakses pada tanggal 23 mei 2018 dari https://biz.kompas.com/read/2017/08/19 /095953328/menaker-ingatkanperusahaan-sediakan-ruang-laktasi-bagiibu-menyusui

Kartini.2018.35 Persen Perusahaan Belum Sediakan Ruang Laktasi.Diakses pada tanggal 8 Agsutus 2018 dari https://www.republika.co.id/berita/nasio nal/umum/18/04/20/p7h604328-35persen-perusahaan-belum-sediakanruang-laktasi

Kemenkes.2013.Kementrian Kesehatan akan Pantau Fasilitas laktasi di Tempat kerja Diakses pada tanggal 25 mei 2018 dari https://www.antaranews.com/berita/517 997/kementerian-kesehatan-akanpantau-fasilitas-laktasi-di-tempat-kerja

Permenkes.2013.Peraturan Menteri Kesehatan Republik Indonesia Nomor 15 Tahun 2013. Diakses pada tangal 4 mei 2018 dari http://www.kesjaor.kemkes.go.id/docum ents/01_Permenkes\%20No.15\%20thn\% 202013\%20ttg\%20Fasilitas\%20Khusus \%20Menyusui\%20dan\%20Memerah\%2 0ASI.pdf

Pusdatin.2013. Kementerian Kesehatan akan pantau fasilitas laktasi di tempat kerja.Diakses tanggal 21 april 2018 dari https://www.antaranews.com/berita/517 997/kementerian-kesehatan-akanpantau-fasilitas-laktasi-di-tempat-kerja

Riskesdas.2013.AIMI Terus Dorong Fasilitas Ruang Menyusui Pada Ibu Bekerja.Diakses pada tanggal 21 april 2018 dari https://www.antaranews.com/berita/509 736/aimi-terus-dorong-fasilitas-ibumenyusui-di-tempat-kerja 
Rizkiandini.2014.Hubungan Pekerjaan Ibu Dengan Pemberian ASI Eksklusif Pada Balita di POSYANDU Bougenville Gayaman Mojoanyer Mojokerto.Diakses pada tanggal 03 Agustus 2018 dari http://repository.poltekkesmajapahit.ac.i d/index.php/PUBKEP/article/viewFile/570/483

SDKI.2012.Laporan Pendahuluan SDKI 2012.Jakarta

Sandra.2017.Perlu Segera Dibuat Regulasi Ruang ASI di Pabrik.Diakses pada tanggal 9 Agustus 2018 dari https://radarbanyumas.co.id/perlusegera-dibuat-regulasi-ruang-asi-dipabrik/

Susenas.2009.Ibu Bekerja Bukan Alasan Menghentikan Pemberian ASI Eksklusif. Diakses pada tanggal 25 Mei 2018 dari http://www.depkes.go.id/pdf.php?id=16 $\underline{62}$

Suwono.2013.Ruang Laktasi di Tempat Kerja Bisa Bikin Karyawati Makin Produktif.Diaskes pada tanggal 07 agustus 2018 dari https://health.detik.com/beritadetikhealth/d-2292940/ruang-laktasi-ditempat-kerja-bisa-bikin-karyawatimakin-produktif

UNICEF.2016. Jutaan bayi di Indonesia kehilangan awal terbaik dalam hidup mereka. Diakses pada tanggal 2 agustus 2018 dari https://www.unicef.org/indonesia/id/me dia_25473.html

Wageindicator Foundation.2014.Tantangan Ibu Bekerja Untuk Menyusui.Diakses pada tanggal 25 mei 2018 dari https://gajimu.com/main/tipskarir/Tentang-wanita/tantangan-ibubekerja-untuk-menyusui

Wiandani.2017.Apa yang terjadi jika perusahaan tidak menyediakan ruang ASI.Diakses pada tanggal 9 agustus 2018 dari http://buruh.co/apa-yangterjadi-jika-perusahaan-tak-

menyediakan-ruang-laktasi-2/ 